\title{
A Research on the Reflection of Online Brand Promise in Open and Distance Education
}

\author{
Berrin Özkanal \\ Faculty of Open Education, Anadolu University, Turkey
}

Copyright $(2019$ by authors, all rights reserved. Authors agree that this article remains permanently open access under the terms of the Creative Commons Attribution License 4.0 International License

\begin{abstract}
The purpose of this study is to investigate whether open and distance education institutions, which are known as mega universities, utilize information and communication technologies in education and reflect the brand promises online, and to determine which brand values (functional and emotional) they use in communication. This study on online brand communication in open and distance education institutions is a descriptive study to determine the current situation. The research data were collected from the qualitative measurement tools by the content analysis method. The scope of the research consists of the websites open and distance education institutions which are called mega universities, with over 100,000 students. The web site of thirteen universities, which were selected by means of meaningful sampling among these universities, were examined with content analysis method within the scope of the research and the collected data were then evaluated by fuzzy logic and clustering analysis methods. As a result, the universities that are examined reflect the online brand promise through different websites with different scores on the variables that make up the functional and emotional values and there are differences in reflecting the brand promises among the universities, and emotional values are more important than functional values.
\end{abstract}

Keywords Brand Promise, Functional Values, Emotional Values and Open and Distance Education

\section{Introduction}

The rapid spread of information because of the development of information and communication and increasing international competition as a consequence of globalization has entailed the reshaping of the required profile of people nowadays and caused to be used different methods in education. These new teaching methods include different teaching approaches such as lifelong learning, distance education, e- learning and take part in the center of learning strategies of European Union and UNESCO [1].

Open and distance education came up for different needs to increase the higher education facilities, to give the opportunity of education to adults, to enhance professional development, to perform innovations and to ensure the economical use of resources for political, economic and educational reasons firstly [2]. As for today, the structure of open and distance education has undergone a paradigm shift depending upon the reasons such as; the development of information and communication technologies flexibility, technological infrastructure, program variety, innovative teaching approaches [3]. With the said developments, the conditions of competition experienced in the field of education emphasize the necessity of strategically good management of the higher education institutions, which provide both formal and distance education institutions, in order to provide quality service at national and international scale, and the necessity of certain standards of university education, especially that distance education has a strategic importance [4].

In this intense competition environment, universities can make a difference with the various services, approaches and strategies they have developed especially for their target groups and they are able to be one step ahead of their competitors. Branding, which is one of the approaches that can make a difference for institutions, plays an important and necessary role in the differentiations of universities today $[5,6]$. With the developments in information and communication technologies, the concept of branding has changed and the concept of online branding has come up and has made a significant contribution to the branding of higher education institutions [7, 8]. Web sites are seen as an integral part of brand communication, both visually and in content, for universities that use different tools and methods from Web sites to social media to create brand value [9] and it is emphasized that it is important to evaluate the specific characteristics of university websites [10].

In the area of distance education, branding is as important or even more important as formal education institutions. This is due to the fact that distance education is 
based on information and communication technologies nowadays and students are in different places and times. In this sense, branding, as well as providing competitive advantage to distance education institutions, is an important pillar of corporate communication. Therefore, online branding provides both competitive advantage for open and distance education institutions and maintains its importance as an important approach in attracting target groups to the organization.

The purpose of this study is to investigate whether open and distance education institutions, which are known as mega universities, utilize information and communication technologies in education and reflect the brand promises online, and to determine which brand values (functional and emotional) they use in communication. The following questions are sought to answer:

Is there a difference among universities in communicating brand promises through the websites of open and distance learning institutions?

What are the values that open and distance education universities use while delivering their brand promises through their websites?

\subsection{Branding in Formal and Distance Higher Education Institutions}

One of the most frequently used definitions for the brand is Kotler and Gertner [11] and the brand definition of the American Marketing Association [12]. Both definitions are defined as the name, symbol, design or various combinations of the products that the brand offers to the people who sell the products for the purpose of identifying these products and distinguishing them from their other counterparts in the market.

With the increasing number of studies on the brand, the definitions related to the brand have also become different and the definitions that reveal the psychological impact of the brand on the consumer have started to take place in the literature. One of these definitions by Kotler and Gertner [11] states that the brand differentiates the products from each other and promises a value to the consumer and directs the behaviors by revealing the beliefs and feelings of the consumers. Thus, it is stated that the brand accelerates the information processing and learning process of the consumer and provides a shortcut and a promise of value to the decision of purchase given to the consumer. Some researchers conducting studies in the field of branding provide insight into the fact that brand definitions are based on emotional and rational factors [13, 14]. While some brands address the rational aspects of consumers, some brands address the emotional aspects of the consumer's such as familiarity or sense of belonging. Balmer and Gray [15] have used the term mark brand promise as a result of the idea of a brand's total commitment to clients' physical and emotional benefits. de Chernatony [16] refers to the brand as a set of functional and emotional values that promise a unique and pleasant experience

Bennett and Ali-Choudhury [17] researchers on branding in higher education, have defined branding in higher education as an element that shows the current capacity of the students who demonstrate the different aspects of the organization, while creating confidence in the capabilities of the higher education point and increasing the interest of successful students towards this organization. For this reason, branding efforts of higher education institutions require communication efforts towards internal and external stakeholders (potential students, parents, employers, etc.). However, in studies on branding in higher education; Stamp [18] discusses the reasons for branding, which are on the agenda of higher education institutions in the UK, Sevier [19] universities with a good brand will attract more quality students, Chapleo [20] elements of a successful university brand and Schee [21] discuss the issues of creating brand dependence on students as a customer In line with these studies, branding activities and developed models in different areas have been applied to universities with some changes [20].

Bennett and Ali-Choudhury [22] highlight the three main content available in a university brand. These; the sum of the promises offered to the outside world regarding the benefits of the brand is an aesthetic naming and external communication types (symbolic and external representation) defining a set of distinctive features and brands that define the natural nature and reality of the brand. It is argued that universities should consistently link all of the promises promised in communication to the actual characteristics and capabilities of an institution

Capleo et all [23] emphasizes the importance of developing the 'brand promise' of universities before communicating with the target audiences and it is stated that 'brand promise' should be elaborated first. The brand promise is seen as the main theme of the 'brand experience' and it is stated that the brand promise consists of three values, functional, emotional and social values [24]. Keller [25] states that functional values consist of brand essence, product characteristics, benefits and attitudes, and emotional values consist of 'people and relationships'. Chapleo et all [23] state that 'functional' values are the basic condition for managing universities' quality and innovation, and 'emotional' values have empathy characteristics that brands present to their target audiences, and that the combination of these characteristics together form the brand personality traits of the university. They therefore agree that a university brand must communicate both 'cognitive' and 'emotional' extends.

It is important that distance education institutions, like the institutions providing formal education, can create brand personality traits with their functional and emotional values. Although these values are similar to the values in the formal education institutions, (especially the distance between the students' being in different times and places, 
and the lack of sense of belonging etc.) can vary. The environment of a formal higher education institution is defined as a community of support services, including the learning environment, library, information technology, course, accessibility and specialist faculty and staff [22]. But, in higher education institutions, which provide distance education, this consists of environmental support services. In today's environment, especially student support through web sites; Information support and personal data are carried out in two ways [26]. Information on the Web (student-related regulations, student status, faculty entry, history, teaching environment and methods etc.) provides information on a wide range of topics. Personal data support refers to the need for students to access and update their personal information in the institution data. The learning environment of a higher education is a conglomerate of support services including the library, information technology, tutoring, financial aid, as well as accessible, caring, and expert faculty and staff [22].

The biggest disadvantage of distance education which is different from formal education is distance and loneliness. Students' connection with the institution, to get information, to establish a relationship with faculty members and to develop community membership identities, in other words, problems such as feeling sense of belonging are important and basic problems [27]. Adaptation and support from the environment within and outside the institution means good education and new students. For this reason, the support services provided by the internet tools (web sites, social media environments etc.) reveal the necessity of the use of emotional values as well as functional values in the creation of brand promise by the distance education institutions.

\subsection{Online Branding}

Online branding is 'the use of online channels to support brands that are the sum of the features of a product, service or organization perceived and experienced by users, customers or other stakeholders' [28]. In terms of marking, it is important that activities in online environments support the consumer-oriented brand value [29, 10]. Consumers are now living their brand experience with Internet tools and environments and matching this experience with the brand value they perceive. Increasing interest in branding on the Internet is also an issue to be emphasized in higher education. Simmons [10] defines the new Internet brand strategies as 'e-branding' that can help them create differences by interacting with customers Rowley [7] demonstrates the need to create an online brand, and the elements that contribute to this experience are referred to as 'relationship'. One of the first online higher education branding studies in the field of online branding in higher education is the research carried out to determine which brand personality the institutions offer in 2006. In this study, brand personality was measured by examining the websites of 12 South African Business Schools using the Brand Personality Scale developed by Aaker (1997) [30]. The South African study was followed by the comparison of Swedish universities with online brand personalities. As a result of the research, it has been revealed that some higher education institutions have open brand personalities [31]. Research by Carrillo et al [32] addresses how Spanish universities conduct brand communication through their websites and discusses success and failures in online communication and is defined as the means by which websites communicate with internal and external audiences that allow organizations to achieve greater competitiveness.

Palacio, Meneses \& Perez [33] in their research on the role of Web sites in branding of universities in online branding, have suggested that institutions with a strong distinctive image will be in a better position in the future. Simmons [10] states that Web sites are important both as visual and content in brand communication. Therefore, it is considered important that Web sites should play a specific role in the branding of universities and that they offer brand promises through universities' Web sites [23].

\subsection{Factors Creating Brand Value in Distance Education}

Universities are not limited to reflect the values of the brand, just like education and research. Universities should reflect to their target groups new functional values such as innovation and international projection with traditional values such as teaching, research or management [23]. Based on these values, it is important to base on emotional values as well. The university environment and social responsibility are the emotional factors put forward by Chapleo et all [23] and constitutes a base to provide a competitive advantage to create an online brand.

Priority areas emerged by determining European Higher Education Area priorities for higher education institutions over the next decade include the social dimension of the process, equal access, employability, lifelong learning, student-centered learning and the task of teaching of higher education institutions, innovation in education and research, international openness, mobility, data collection, multidimensional transparency tools and financing of higher education [34]. Therefore, higher education institutions should be able to use these values to create online brands.

These values are pointed out as Research, Teaching, Management, International Projection, Innovation and Social Responsibility according to UNESCO (2008) Higher Education Institutions Report and [1, 23]. In addition to these basic variables, the values of the Leuven Declaration [34] and the employability mentioned in Capleo et all [23] and the environment of the university environment (support services) which form the environment of open and distance education institutions 
titles have been added to these values. These basic values that constitute the variables of the study; Management, Research, Teaching, International Projection, Innovation, Social Responsibility, Employability and University Environment (Support Services) are explained below [34, 23].

Management: It is stated as one of the important and necessary values for communication. This value, together with higher education competitive conditions "entrepreneurial university 'concept has brought to the fore. Cooperation with universities and industry to come together to do the 'entrepreneurial university' is referred to as the birth of the system [35]. Robertson [36] summarizes the characteristics of the entrepreneurial university as follows; the strong leadership that develops the entrepreneurial capacities of all university actors, the strong links with external stakeholders, the increase of university-industry collaborations, the application of innovative learning techniques that lead to entrepreneurial action, the effective flow of information between institutions and the multidisciplinary approaches to education reflecting the solution-oriented and real-world experience for world problems. The statements related to these values can be found on the web pages of the universities and studied under these headings; the clarification of activity reports and strategic plans, mission, vision and values, entrepreneurial university features (technology transfer, academic initiative, by-product creation, entrepreneurial activities) and the existence of flexible management structures of university management (national, local, institutional, faculty and unit level).

Research: It is an important factor that research for universities should be publicly available and that the results of the research are freely accessible to everyone [37]. According to UNESCO's World Education Conferences report [1] higher education institutions are seen as centers of research, teaching and intellectual discussions. However, it is stated that the 'research' variable may affect the perception of the image of a higher education institution [38]. The criteria such as access to research on the Web sites of universities, the existence of research values on the Web sites, and the availability of books, articles, research reports, patents and access to distance education are covered under this heading.

Teaching: This variable is strongly associated with teaching quality. It is recommended that the institutions investigated emphasize such attributes, developing mechanisms to ensure quality of the teaching offered with a well-developed education programme, up-to-date content in line with the labour market, and a continuing search not only for the qualification and training of tutors and staff, but also for the management of their actions when they are in contact with students [39]. The topics related to the 'Teaching' variable in the Web sites of universities; standard or different curriculums (existence of special programs and interdisciplinary programs), teaching environments (basic teaching environments of open and distance education; books, television programs, e-learning environments, academic counseling services, live lessons etc.) the presence of activities [39] and the existence of values on the web sites and the application of different models with web-based and online methods (MOOCS, etc.) are the properties emphasized under the heading of teaching.

International Projection: Internationalization includes the policies and practices undertaken by academic systems and institutions - and even individuals - to cope with the global academic environment. The motivations for internationalization include commercial advantage, knowledge and language acquisition, enhancing the curriculum with international content, and many others [40]. Internationalization efforts of universities contribute to global brand [41]. This value has been evaluated on Web sites as; international business opportunities, international studies and mission declarations internationally, international institutional researches, international accreditation and collaborations.

Innovation: Developments in the field of innovation policies since the 1980s have led to the establishment of closer relations between the university and industry, unlike the previous periods. Issues related to technological, educational and management innovation constitute the vital qualities of the university. Kjaersdam (2001) argues that university innovation is a key value directly linked to management, research and teaching, which should be reported in the brand promise. Technological and innovation policies, research finance and commercialization of scientific development are the features required for the differentiation of universities [42]. The main criteria for this variable are; technological innovation, educational innovation, management innovation that should be expressed in their mission and vision statements, in short, whether there is the image of innovation or not.

Social Responsibility: Social responsibility is a characteristic feature of the university. Universities are expected to be able to share their achievements by continuously interacting with the local, regional and national community. This is due to the concept of a public service, as well as social responsibility in the context of the globalization of the local and regional move [23]. UNESCO [1] states that social responsibility is not only related to higher education institutions, but also to research and teaching principles and strategies, as well as the development of inclusion policies to respond to the learning needs of young and marginalized and vulnerable youth and adults. In this context, higher education institutions should promote ethical values and attitudes that strengthen their responsibilities to the community and their sensitivity to local, national and global realities among students. Equal access of every individual to the facilities of the university, the fulfillment of the social duties of the 
universities and social responsibility campaigns are the criteria that are considered in this variable.

University Support Services: Support services in distance education include different support services offered by universities to students. The biggest disadvantage of the open and distance education system for students is that they cannot feel belonging to the institution they study. The duty of support services is to provide the information which is available at any time by the opportunities of information and communication technologies by minimizing the feeling of being away from the campus which is one of the biggest problems of open and distance education students, to gain them the sense of belonging, to adopt them to culture of institution. In addition to this, it is aimed to create a healthy and effective communication among themselves and the institution by means of news and discussion groups and social media environments to be formed on the Internet. Student support to be provided through the Internet and its tools in open and distance education institutions is carried out in two ways; information support and personal data [26]. Information counseling enables students to learn about a wide range of subjects such as student regulations, student status, entrance to the faculty, teaching environment and methods by fronting to corporate Web sites. In the institutions providing education by open and distance education system, the basic support services are evaluated as: Student communities, library, technological support, academic support, administrative support and etc.

Employability: Graduation prospects are post-graduation job and career prospects, which includes the perception of employability or practical usefulness of the education and the perception of future social and economic status gained [43].

This seems to indicate that students are very much sensitive and influenced by the expectations and beliefs regarding the experiences of the academic life, as well as how easily it will be to find a job after finishing the course. Other important issue that deserves a detailed attention is that the communication, job opportunities and course constructs, all have almost the same influence on image. From a practical standpoint, this means that universities' managers should pay attention to all factors instead of investing a great deal of resources and efforts just on one dimension [38].

Decisions taken in the Bologna Process on Employment are to strengthen employability in line with the needs of Europe, to combine innovative skills and competencies of graduates with current knowledge that can meet the needs of society and the business world [44]. In this direction, the criteria for the web sites for this value; are the following: The Alumni Association, career services, career office and career research programs and links with employers.

\section{Method}

This study on online brand communication in open and distance education institutions is a descriptive study to determine the current situation. The research data were collected from the qualitative measurement tools by the content analysis method. The scope of the research consists of the websites of open and distance institutions, which are called mega universities, with over 100,000 students [45]. The web site of thirteen universities, which were selected by means of meaningful sampling among these universities, were examined with content analysis method within the scope of the research and the collected data were then evaluated by fuzzy logic and clustering analysis methods.

Table 1. Open and Distance Education Institutions

\begin{tabular}{lll}
\hline Country & Institution & Establishment \\
\hline China & Open University of China & 1979 \\
\hline France & $\begin{array}{l}\text { France National Centre for } \\
\text { Distance Education }\end{array}$ & 1986 \\
\hline India & Indira Gandhi National Open Uni & 1985 \\
\hline Indonesia & Universitas Terbuka & 1984 \\
\hline Bangladesh & Open University & 1992 \\
\hline Korea & Korean National Open Uni & 1982 \\
\hline South & University of South Africa & 1945 \\
\hline Africa & Universidad Nacional de & 1972 \\
\hline Spain & Education & 1982 \\
\hline Turkey & Anadolu University & 1969 \\
\hline England & Open University & 1970 \\
\hline Canada & Athabasca University & 1974 \\
\hline Pakistan & Allama Iqbal Open Uni & 1987 \\
\hline Iran & Payame Noor University & 1978 \\
\hline
\end{tabular}

\subsection{Data Collection and Procedures}

Content analysis is a technique that provides an objective, systematic or quantitative examination of the observed content of any communication [46]. Content analysis is a method that does not alter or interfere with the phenomenon being investigated and it is stated that Web sites are open to content analysis among other forms of communication [47] and that content analysis is the most important feature to be able to present healthy data is objectivity [48].

The website of the thirteen universities identified in the content analysis section of the study included eight different variables; social responsibility, university support services and employability. These criteria are as follows;

The existence of information about each variable; it is stated that information is required to communicate a brand through the website, but the content must be integrated into the design [49].

Content in different languages: In order to develop the brands of universities in a competitive environment, the website content should be translated into different languages [50, 51-52]. 
Strengthening the messages with statistical and visual audiovisual images; the proper use of tables, graphics and visualization techniques on websites, and the understanding of quantitative information as part of web design [53].

The location of the message for each variable; site design is one of the important factors affecting customer satisfaction and it is necessary for a brand [54, 53].

Adaptation of information for each variable to different stakeholders: individual preference information is included on the website to provide direct content to each shareholder [55].

Five units of analysis for eight variables in the websites examined and seventeen expressions related to these units with values of 1 to 5 ; 5 was coded as 'very good', 4 'good', 3 'medium', 2 'bad' and 1 'very bad'.

The variables examined in the study were rated 1 to 5 and 5 were coded as 'very good', 4 'good', 3 'medium', 2 'bad' and 1 'very bad'. Encodings were realized between June 15 and July 15, 2018 by 3 different knowledgeable people in the field. In the content analysis, Miles \& Huberman [56] developed a formula using the concept of reliability between coders, based on the consensus between the coders in the content analysis. In this study, this rate was found to be $92 \%$.

Table 2. Clusters and distance values relating to universities examined within the scope of the research

\begin{tabular}{lllll}
\hline Iteraton & \multicolumn{5}{l}{ Change in Cluster Centers } \\
\hline & $\mathbf{1}$ & $\mathbf{2}$ & $\mathbf{3}$ & $\mathbf{4}$ \\
\hline 1 & .816 & 1.146 & .000 & 1.470 \\
\hline 2 & .000 & .000 & .000 & .000 \\
\hline
\end{tabular}

\subsection{Data Analysis}

In this study, fuzzy logic and clustering analysis methods were used to analyze the data collected by content analysis method. Fuzzy logic is a method in response to the false-correct propositions of classical logic forms three or more propositions [57]. The basic idea is that a proposition may be 'true', 'false', 'very true', 'very false', 'very, very false' etc.. Main features of fuzzy logic; can be put in order as having the correct degrees of accuracy that expressed verbally as 'true', 'very true', 'more or less true', having inference rules which are not definitely valid but approximate, having a degree of each concept, having each logical system blurred, the interpretation of information by the flexibility or equivalence of variables of fuzzy constraints [58].

The analysis of the variables (functional and emotional values) in the web sites of open and distance education institutions, studied with content analysis, were carried out by Fuzz Interference System (FIS), FIS is a calculation system based on fuzzy cluster theory, fuzzy if-so rules and fuzzy logic concepts and it is defined as the method of matching an input space to output space [59]. The data obtained in the study were analysed at the help of fuzzy editor in Matlab. In forming membership clustership in fuzzy editor, the functional and emotional values obtained via content analysis method of web sites universities were determined as input and brand promising as output. The fuzzy clusters were formed by assigning these two inputs at five membership functions as "very bad", "bad", "medium", "good" and "very good" and the outputs on brand promising of these variables as "non", "little", medium", "high", "very high". In order to form rulebase from these fuzzy clusters $5 \times 5=25$ rule was written since there are two input and in each input there are five degrees. Then the expressions in the rule table for brand promising were graded as ( $5=$ very high $),(4=$ high $),(3=$ medium $),(2$ $=$ little) and $(1=$ poor $)$ and these calculations were carried out via Matlab.

In order to determine whether the universities examined within the scope of the research can be grouped according to the way they transmit their brand promises via internet, clustering analysis is used from multivariate statistical methods. In the analysis, $\mathrm{k}$-mean ( $\mathrm{k}$-medias) technique was used from non-hierarchical clustering methods. Clustering analysis is a method used for grouping and presenting summative information to the researcher, taking into account the basic characteristics of individuals or objects [60]. Unlike other multivariate statistical methods, clustering analysis accepts the distance values of variables rather than normality, linearity and homogeneity assumptions [61]. The method used in the clustering analysis is the k-mean (k-medias) technique which is proven to be suitable for the grouping elements. This technique demonstrates the process of assigning each unit to the nearest cluster with $\mathrm{k}$ [62] and dividing the units into $\mathrm{k}$ clusters; the units are assigned to the closest cluster in terms of value, the distance is usually determined by using Euclidean distance, then the units are calculated by finding the new value of the cluster and finally by the repetition stages until no assignment is made [63]. In this study, Squared Euclidean Distance Method measurement was used to calculate the distance. This method is a kind of distance measurement depicting similarities or dissimilarities in calculating the distance between variables. Since the data in this study were obtained from binary observations and this method was most commonly and most effectively used to measure the similarity between two objects [64], Squared Euclidean Distance was used.

\section{Findings}

Table 1 shows the number of repetitions and indicates that the program consists of 4 clusters in 2 repetitions. According to these data, the universities examined within the scope of the research are divided into four groups. The first group of universities (.816), the second group of universities (1.146), the third group of universities (.000) and the fourth group of universities (1.470) have the 
distance points. In line with these data, it can be said that first cluster is farther than the third cluster.

Table 3. Results of clustering analysis according to coding points given to web site content of universities examined within the scope of the research

\begin{tabular}{|c|c|c|}
\hline Universities & Cluster & Distance \\
\hline Open University & 1 & .816 \\
\hline Athabasca University & 1 & .577 \\
\hline University of South Africa & 1 & 1.000 \\
\hline Korea National Open University & 4 & 1.470 \\
\hline Open University of China & 4 & .980 \\
\hline $\begin{array}{l}\text { Indira Gandhi National Open } \\
\text { University }\end{array}$ & 4 & 2.040 \\
\hline Anadolu University & 4 & 1.470 \\
\hline Universidad Nacional de Educacion & 4 & 1.327 \\
\hline Bangladesh Open University & 2 & 1.346 \\
\hline $\begin{array}{lll}\text { Sukhothai } & \text { Thammatrirat } & \text { Open } \\
\text { University } & & \\
\end{array}$ & 2 & .901 \\
\hline Universitas Terbuka & 2 & 1.146 \\
\hline $\begin{array}{l}\text { France National Centre for Distance } \\
\text { Education }\end{array}$ & 2 & 1.346 \\
\hline Iran Payame Noor University & 3 & .000 \\
\hline
\end{tabular}

Table 3, which is owned by the surveyed clusters of universities, and shows the distance from each other in accordance with the scores received by the university. According to the table; in the research, four clusters were obtained as a result of the analysis made on variables of functional (research, teaching, management, innovation, international projection) and emotional values (social responsibility, university support services and employability). The number of elements of the first cluster is three. These; Open University (England), Athabasca University (Canada) and the University of South Africa (South Africa) open and distance education universities. The number of the universities in the second cluster is four. Universities in this group; Sukhothai Thammatrirat Open Uni (Thailand), Universitas Terbuka (Indonesia), Bangladesh Open University (Bangladesh) and France National Center for Distance Education (France). The only university in the third cluster is Iran Payame Noor University (Iran). The fourth cluster consists of five universities. These; The Open University of China (China), Korea National Open University (Korea), Universidad Nacional de Educacion (Spain), Anadolu University (Turkey) and Indira Gandhi National Open University (India).

Table 4 shows the means of the functional and emotional values in the clusters and the mean of the online brand promise as a result. Accordingly, it is seen that the first cluster has the best mean and the third cluster has the weakest mean. As shown in the table, the emotional values of the universities in the first cluster (mean 4.89 points) are slightly higher than the functional values (mean 4.80 points) and the online brand promises (mean 5.00 points) of these universities can be said to be 'very good'. Looking at the universities in the fourth cluster, functional values (mean 3.64 points) and emotional values (mean 3.66 points) are almost equal. It can be said that the online brand promises of the universities in this cluster reflect a 'good' rating with a mean of 3.80 points. On the other hand, the functional values are (mean 3.00 and 1.80 points) and emotional values are (mean 2.66 and 1.67 points) of the universities in the second and third cluster and it can be seen that the universities in these two clusters reflect the functional values are better than their emotional values. According to these data; it can be said that the brand promise of the universities in the second cluster (mean 2.75 points) is 'moderate' and the brand promise (mean 1.00 points) of the university in the third cluster is 'weak'.

Table 4. Functional and emotional values with brand promise points of the web sites of the universities researched in the study

\begin{tabular}{lllll}
\hline Values & 1 & 2 & 3 & 4 \\
\hline Functional Values & 4.80 & 3.00 & 1.80 & 3.64 \\
\hline Emotional Values & 4.89 & 2,66 & 1.67 & 3.66 \\
\hline Brand Promise & 5.00 & 2.75 & 1.00 & 3.80 \\
\hline
\end{tabular}

Table 5. University websites cluster mean ratings for variables researched in this study

\begin{tabular}{lllll}
\hline \multirow{2}{*}{ Variables } & \multicolumn{2}{l}{ Cluster } & & \\
\cline { 2 - 5 } & 1 & 2 & 3 & 4 \\
\hline Teaching & 5.00 & 4.00 & 1.00 & 3.80 \\
\hline Research & 4.67 & 3.50 & 2.00 & 3.40 \\
\hline Management & 5.00 & 2.75 & 2.00 & 3.40 \\
\hline International Projection & 5.00 & 1.75 & 2.00 & 3.80 \\
\hline Innovation & 4.33 & 3.00 & 2.00 & 3.80 \\
\hline Social Responsibility & 4.67 & 2.25 & 2.00 & 3.80 \\
\hline Support Services & 5.00 & 3.25 & 2.00 & 4.00 \\
\hline Employability & 5.00 & 2.50 & 1.00 & 3.20 \\
\hline Brand Promises & 5.00 & 2.75 & 1.00 & 3.80 \\
\hline
\end{tabular}

Table 5 shows the variables that make up the emotional and functional values in the universities studied and the resulting online brand promise. According to the table, It is seen that the mean value of 'teaching', 'research', 'management' and 'international projection' variables at the universities in the first cluster is the highest with 5.00 points and the mean of 'innovation' variable is the lowest with 4.33 points. When the variables constituting the emotional values of the universities in the first cluster are examined, the mean of 'university environment' and 'employment' variables is the highest with 5.00 points, while the mean of 'social responsibility' is slightly lower with 4.67 points. From the functional values of the universities in the fourth cluster, the mean of 'teaching', 'international projection' and 'innovation' variables is high with 3.80 points, while the mean of 'research' and 'management' variables is slightly lower with 3.40 points. 
When the mean values of universities in this cluster are examined, it is seen that 'university environment' and 'social responsibility' variables are higher with 4.00 and 3.80 points, and 'employment' variable is lower with 3.20 points. In line with this data, it can be said that universities in this cluster reflect almost both emotional and functional values equally on their web sites with different variables. The highest mean in the second cluster belong to functional values of 'teaching', 'research' and 'innovation' variables with 4.00, 3.50 and 3.00 points while the lowest mean belongs to 'international projection' variable with 1.75 points. International projection information and language acquisition, the enrichment of the course programs with international content, and the international level of university engagement issues [40] and universities are contributing to the internationalization efforts of internationalization efforts [41]. The low level of 'international projection' on the websites of the universities in this cluster may be indicative of the fact that websites are not in different languages, act with more local elements and do not use international programs, research and collaborations. The universities in this cluster have a mean of 3.25 and 2.50 points in emotional values which is higher, and 2.25 mean in the social responsibility variables which is lower. In the third cluster, It is seen that the 'teaching' variable from functional values in the single university is lower with an mean of 1.00 points, 'research', 'management', 'international projection' and 'innovation' variables are slightly higher with an mean score of 2.00 , while in emotional values' employment the variable 'social responsibility' and 'university environment' are slightly higher than the mean score of 2.00 .

From this data, it can be said that the best reflected value among functional values (excluding the third set) is 'teaching'. This is due to the fact that teaching for universities is a basic function and that this basic function is used by open and distance learning universities as an important variable in conveying the promise of online brand. 'University support services', which constitute the emotional values, are the best mean score in all four clusters. This variable, which is considered as university environment in formal education, is considered as 'university support services' variable in open and distance education universities and the reason why this variable has high scores in four university groups is thought to be due to the nature of open and distance education. This is because the fundamental difference of universities that provide open and distance education is that learners need to have more support from support services due to their presence in different places and times and because of their low belongings.

Table 6. Distances of university web sites by clusters in the scope of research

\begin{tabular}{lllll}
\hline Cluster & $\mathbf{1}$ & $\mathbf{2}$ & $\mathbf{3}$ & $\mathbf{4}$ \\
\hline $\mathbf{1}$ & & 6.323 & 9.730 & 3.709 \\
\hline $\mathbf{2}$ & 6.323 & & 4.451 & 3.142 \\
\hline $\mathbf{3}$ & 9.730 & 4.451 & & 6.177 \\
\hline $\mathbf{4}$ & 3.709 & 3.142 & 6.177 & \\
\hline
\end{tabular}

Table 6 shows the distances between the final cluster centers. According to this, we can say that the two closest clusters are 1 and 4 , and the most remote clusters are 1 and 3. In line with this data, it can be said that there is no significant difference between the universities in the first and fourth clusters in transferring the online brand promise, while there are significant differences between the universities in the first cluster and the university in the third cluster. According to these data, it can be said that the Open University (England), Athabasca University (Canada) and the University of South Africa (South Africa) are the universities that have the strongest brand promise of open and distance education universities while Iran Payame Noor University, which is the single one in the third cluster, has weak on line brand promise.

Table 7. ANOVA results of variables related to university websites in the scope of research

\begin{tabular}{lllllll}
\hline & \multicolumn{2}{l}{ Cluster } & Error & & F & Sig. \\
\cline { 2 - 8 } & Mean Square & df & Mean Square & df & & \\
\hline Teaching & 4.041 & 3 & .089 & 9 & 45.462 & .000 \\
\hline Research & 2.07 & 3 & .541 & 9 & 3.828 & .051 \\
\hline Management & 3.76 & 3 & .217 & 9 & 17.355 & .000 \\
\hline International Projec. & 7.073 & 3 & .172 & 9 & 41.069 & .000 \\
\hline Innovation & 1.921 & 3 & .163 & 9 & 11.790 & .002 \\
\hline Social Responsibility & 4.287 & 3 & .246 & 9 & 17.405 & .000 \\
\hline Support Services & 2.981 & 3 & .083 & 9 & 35.769 & .000 \\
\hline Employability & 5.503 & 3 & .422 & 9 & 13.032 & .001 \\
\hline Brand Promises & 5.227 & 3 & .172 & 9 & 30.350 & .000 \\
\hline
\end{tabular}


With ANOVA results whether the variables differ in terms of clusters are examined. In clustering analysis, by making this difference, the difference (distance) between the clusters is made maximum. According to ANOVA analysis in Table 7 , variables, except research variable, differ according to clusters $(\mathrm{p}<0.05)$.

\section{Discussion and Conclusions}

The results of this study, which is conducted to determine whether open and distance education institutions that benefit from information and communication technologies in education reflect their brand promises online and to determine which values (functional and emotional) they use in making online brand promise through the websites of these universities are as follows:

For the purposes of the research, the first question is that the universities that provide open and distance education reflect their brand promises through their websites. The universities that are examined reflect the online brand promise through different websites with different scores on the variables that make up the functional and emotional values and there are differences in reflecting the brand promises among the universities. The second question to be sought within the scope of the research is what universities (functional and emotional) use when reflecting online brand promises through the websites of open and distance education universities. According to the results of the study; The open and distance education institutions in the first cluster reflect the online brand promise at the 'very good' level and do so by transmitting emotional values a little more than functional values. Looking at the establishment years of the universities in this cluster (table 2), these three universities in the field of open and distance education are the first established and leading universities, only in the field of open and distance education to provide services and therefore obtained in this field it can be concluded that the experience also succeeds in reflecting the online brand promise of universities.

It can be said that the universities in the fourth cluster (table 4) reflect their online brand promises with both functional and emotional values almost equally and 'good'. The universities in this cluster are universities that offer education in both single and dual modes, and it can be seen from the years of foundation (chart 1) that these universities are universities that have served in the field of open and distance education since 1980s.

The universities in the second and third clusters are universities that reflect their online brand promises in 'medium' and 'weak' levels. It can be said that universities in this cluster have highlighted functional values more than emotional values in reflecting online brand promise (Table 4). As a result of the study, an important finding about the second cluster is the weakness of the 'international projection' variable from the functional values (table 5).
Some of the reasons why universities in this cluster reflect their brand promises on a 'medium level' may be due to the fact that websites are not in different languages, act more by local elements, and do not use international programs, research and collaborations sufficiently. The finding that the universities in these two clusters use functional values (traditional values) in reflecting the brand promise such as formal education universities are consistent with the results of the study conducted by Capleo et all [23] in British universities. However, there may be more reflections of the emotional values expected from the universities that provide open and distance education. Because open and distance education is different from formal education, it is a system in which students are in different places and time, offer flexible learning opportunities to individuals and require two-way communication. Therefore, in the system, it is inevitable that the applications for various support services will be developed to improve the sense of belonging and loneliness of the students and to develop the sense of belonging. The reason for the high value of the 'university support services' variable from emotional values in the universities examined (Table 5) is that can be the use of the opportunities provided by information and communication technologies in the universities that provide open and distance education, being able to bring down the feeling of being away from the campus to the lowest level which is one of the biggest problems of open and distance education, bringing in the sense of belonging to the students and developing students' communication facilities with the institution. On the other hand, the fact that the variables 'social responsibility' and 'employment' have low points (table 5) reveal that these variables should be given as much importance as 'university support services' in open and distance education institutions. It is seen important to perform practices that increase employment, provide social responsibility and integrate with society in open and distance education institutions.

The recommendations presented in the light of the results of this research conducted in order to reflect the online brand promise in open and distance education universities are as follows:

Today, increasing competition in the field of education, especially the open and distance education institutions to maintain their existence and distinguishing from the other institutions reveals the importance of brand and brand communication concepts once again. To create online brand promise in open and distance education for reasons arising from the basic philosophy of open and distance education (distance, belonging, being at different time and place, etc.), to attract students to the system, to keep existing students in the system and to reintroduce them in the system it is recommended that emotional values (social responsibility, support services and employability)to be used as much as or even much more than functional values in creating an online brand promise. However, in the future researches, in reflecting online brand promise in open and 
distance learning institutions in order to research both functional and emotional values on online brand promise's variables in detail apart from content analysis, it is recommended to be realised qualitative and qualitative methods for all stakeholders of the institutions.

\section{REFERENCES}

[1] UNESCO (United Nations Educational, Scientific and Cultural Organization). Quality education, equity and sustainable development: A holistic vision through UNESCO's four World Education Conferences, 20082009. Online available from http://unesdoc. unesco.org/ima ges/0018/001818/181864e.pdf

[2] M. Simonson, S. Smaldino \& S. M. Zvacek. Teaching and learning at a distance. In M. Simonson, S. Smaldino, S.M. Zvacek (Eds.), Foundations of Distance Education, $6^{\text {th }}$. IAP Inc. North Carolina. 2012.

[3] M. Firat. Paradigm shift in distance education in the $21 \mathrm{st}$ century. Journal of Higher Education and Science, Volume 6, No.2, 142-150. 2016.

[4] UNESCO/COL. Perspectives on Distance Education: Lifelong Learning and Distance Higher Education C. McIntosh (Eds.), 2005. Online available from https://unesdoc.unesco.org/ark:/48223/pf0000141218

[5] C. Veloutsou, J.W. Lewis, \& R.A. Patton. University selection: Information requirements and importance. The International Journal of Educational Management, Vo1.8, No. 3, 160-171. 2004.

[6] J. B. Hemsley \& I. Oplatka. Universities in a competitive marketplace: A systematic review of the literature on higher education marketing. International Journal of Public Sector Management, Vol.19, No. 4, 316-338. 2006.

[7] J. Rowley. Online branding, Online Information Review, Vol.28, No. 2, 131-138. 2004.

[8] C. Chapleo. Barriers to brand building in UK universities? International Journal of Non-profit and Voluntary Sector Marketing, Vol, 12, No.1, 23-32. 2007.

[9] M. Schultz, M. J. Hatch \& M. H. Larsen. The expressive organization. Oxford University Press, Oxford, 2000.

[10] G. J. Simmons. I-branding: Developing the Internet as a branding tool. Marketing Intelligence and Planning, Vol. 25, No. 6, 544-562. 2007.

[11] P. Kotler \& D. Gertner. Country as brand, product, and beyond: A place marketing and brand management perspective. Journal of Brand Management, Vol 9, No. 4, 249-261.2002.

[12] American Marketing Association. Brand. Online available from http://www.marketing-dictionary.org, 2014.

[13] L. De Chernatony \& G. McWilliam. Appreciating brands as assets through using a two-dimensional model, International Journal of Advertising: The Review of Marketing Communications Vol 9, 1990, No. 2. 111-119. 2015. Online availablehttps://doi.org/10.1080/02650487.19
90.11107137.

[14] N. Caldwell \& R. Freire. The differences between branding a country, a region and a city: Applying the brand box model. Brand Management Vol. 12, No. 1, 50-61. 2004.

[15] J. M. Balmer \&. E. R. Grey. Corporate brands: What are they? What of them?” European Journal of Marketing, Vol. 37, No. 7/8, 972-997. 2003.

[16] L. De Chernatony. Internal brand factors driving successful financial services brands. European Journal of Marketıng Vol. 40, No. 5/6, 611-633. 2006.

[17] R. Bennett \& R. Ali-Choudhury. Components of the university brand: An empirical study. Proceedings of the 3rd. Annual Colloquium of the Academy of Marketing's Brand, Corporate Identity and Reputation SIG, Brunel University, 12-13 September, 2007

[18] R. Stamp. The new challenge of branding buy-in. Education News, Winter, 7, 2004.

[19] R. A. Sevier. Advancing the brand. University Business, Vol. 10, No.2, 46-51. 2007.

[20] C. Chapleo. What defines successful university brands?" International Journal of Public Sector, Vol. 25, No. 2, 169-183. 2010.

[21] V.A.B. Schee. Students as consumers: Programming for brand loyalty”. Service Marketing Quarterly, Vol.32, No.1, 32-43. 2010

[22] R. Bennett \& R. Ali-Choudhury. Prospective students perceptions of university brands: An empirical study". Journal of Marketing for Higher Education, Vol.19, No. 1, 85-107. 2009.

[23] C. Chapleo, M. V Durán, \& A.C Díaz. Do UK Universities communicate their brands? Effectively through their websites?” Journal of Marketing for Higher Education, Vol. 21, No.25-46. 2011

[24] J. Villafañe. The good reputation: Intangible key business value. Pira 'mide, Madrid, 2004.

[25] K. L. Keller. Building \& managing corporate brand equity. In M, Schultz, M J, Hatch M.H Larsen (Eds.), The Expressive Organization. Oxford University Press, Oxford, 115-137. 2000.

[26] O. Simpson. Supporting Students in Open and Distance Learning. Kogan Page, London, 2000

[27] D. Eastmond. Alone but together: Adult Distance Study Through Computer Conferencing. Cresskill, NJ: Hampton Press, 1995

[28] D. Chaffey. What is online branding? Online available from "www.davechaffey.com/ E-Marketing-Glossary, 2008

[29] F. Heldal, E. Sjøvold, \& A. F. Heldal. Success on the Internet-optimizing relationships through the corporate site. International Journal of Information Management, Vol. 24, No. 2, 115-129.2004

[30] R. A. Opoku, R. Abratt \& L.Pitt. Communicating brand personality: Are the web sites doing the talking for the top South African Business Schools? Brand Management, Vol.14, No. 1/2, 20-39. 2006 
[31] R..A. Opoku, M. Hultman, \& E. Saheli-Sangari. Positioning in market space: The evaluation of Swedish universities' online brand personalities. Journal of Marketing for Higher Education, Vol. 18, No.1, 124-144. 2008.

[32] M, Carrillo, A Castillo \& T Sánchez. Brand transmission of Spanish universities in their websites. Historia Comunicación Social Vol. 18. No. Esp. Octubre, 195-205. 2013.

[33] A. B. Palacio, G. D Meneses \& P. J. P. Perez. The configuration of the university image and its relationship with the satisfaction of students. Journal of Educational, Vol. 40, No. 5, 486-505.2002.

[34] Leuven Declaration. The European Higher Education Area in the new decade Communiqué of the Conference of European Ministers Responsible for Higher Education, Leuven and Louvain-la-Neuve, 28-29 April 2009. Online available from http://www.ehea.info/media.ehea.info/file/2 009_Leuven_Louvain-la-Neuve/06/1/Leuven_Louvain-laNeuve_Communique_April_2009_595061.pdf

[35] M. Lazzeroni \& A. Piccaluga. Towards the entrepreneurial university, Local Economy, Vol. 18, No.1, 38-48. 2003

[36] I. Robertson. Comment: How Universities and Graduates Can Thrive. Online available from http://www.independent. co.uk/student/career-planning/getting-job/comment-how-un iversities-and-graduates-can-thrive-918572. 2008.

[37] D. Hegde. Defining the essence ofa university: Lessons from higher education branding”. Economic Development Quarterly, Vol. 19, 373-386. 2005.

[38] P. Duarte, H. Alves \& M Raposo. Understanding university image: a structural equation model approach. International Review on Public and Nonprofit Marketing, Vol.7, No. 1, 21-36. 2010.

[39] R. Costa, \& A. Pelissari. Factors affecting corporate image from the perspective of distance learning students in public higher education institutions. Tertiary Education and Management, Vol. 22, No.4, 287-299. 2016.

[40] P. Altbach, \& J. Knight. The Internationalization of higher education: Motivations and realities, Journal of Studies in International Education, Vol.11, No. 3-4, 290-305. 2007.

[41] J. Knight. Five Myhts about Internalization. International Higher Education, No 62, Winter. 2011. Online available from

https://ejournals.bc.edu/ojs/index.php/ihe/article/view/8532 /7666

[42] F. Kjaersdam,. Innovation in university education cited in Pudlowski, Z. J., Conference proceedings 4th UICEE Annual Conference on Engineering Education; Innovation in Engineering Education, Monash Engineering Education Series, 66-68. 2001

[43] F. Maringe. University and course choice: Implications for positioning, recruitment and marketing", International Journal of Educational Management, Vol. 20, No.6, 466-479. 2006.

[44] Bucharest Communiqué Final Version Report, 2012. Online available from https://enqa.eu/wp- content/uploads/2013/03 /Bucharest-Communique-20121.pdf

[45] M. G. Moore \& G. Kearsley Distance Education: A System
View of Online Learning. Belmont Wadsworth, USA, 2011.

[46] B. Berelson. Content Analysis in Communication Research. Michigan: Free Press. 1952.

[47] E. Babie. The Practice of Social Research (9th ed.). California: Wadsworth, Inc. 2001.

[48] H. G. Stempel III, İçerik Analizi” İletişim Araştırmalarından İçerik Çözümlemesi. Çev: M. Sadullah Çebi. Ankara: Alternatif. 183-213. 2003

[49] G. Christodoulides, \& L. De Chernatony. Dimensionalising on- and offline brands' composite equity. Journal of Product \& Brand Management, 13(3), 168-179.2004.

[50] D. Pickton, D \& A.Broderick. Integrated Marketing Communications. Harlow: Prentice Hall. 2000

[51] R. J. Varey. Relationship marketing: Dialogue and networks in the E-Commerce Era. Chichester: John Wiley \& Sons. 2002.

[52] R. Marcella \& S. Davies. The use of customer language in international marketing communication in the Scottish Food and Drink industry. European Journal of Marketing, Vol. 38, No.11/12, 1382-1395. 2004.

[53] J. P. Lynch \& S. Horton, S. Web style guide: Principles of basic design for the creation of web sites (3th ed). Yale University Press, 2008.

[54] D.M. Szymanski \& R. T. Hise. E-satisfaction: An initial examination. Journal of Retailing, Vol. 76, 309-322. 2000

[55] A. Ansari \& C. F. Mela. E-customization. Journal of Marketing Research, Vol. 40, No. 2, 131-45. 2003.

[56] M. B. Miles \& A. M. Huberman. Qualtive data analyses: An expanded sourcebook (2nd ed). Thousand Oaks, California Sage .1994.

[57] L. A. Zadeh. Fuzzy Sets. Information and Control. Vol. 8, No. 3, 338-353. 1965. Online available from https://doi.org/10.1016/S0019-9958(65)90241-X

[58] N. Baykal \& T. Beyan. T., Bulanık mantık uzman sistemler ve denetleyiciler, Bıçaklar Kitabevi, Ankara. 2004.

[59] G. Bojadziev, G., Bojadziev, M. Fuzzy logic for business, finance and management, World Scientific, London. 2007.

[60] Ş. Kalaycı. SPSS uygulamalı çok değişkenli istatistik teknikleri. (5. bask1). Asil Yayın Dağıtım. Ankara. 2010.

[61] Kayri, M. Araştırmalarda iki aşamalı kümeleme analizi ve bir uygulaması. Eğitim Araştırmaları Dergisi, Cilt.. 28. No. 1, 177-189. 2007.

[62] J. MacQueen. Some methods for classification and analysis of multivariate observations. Proceedings of the Fifth Berkeley Symposium on Mathematical Statistics and Probability, University of California Press, Berkeley, California, 1967. Online available from https://projecteucli d.org/euclid.bsmsp/1200512992

[63] P. M. Norusis. SPSS for Windows. Base System. SPSS Inc. Chicago. 1993.

[64] F. J Hair, E. R. Anderson \& L. R. Tatham. Multivariate data analysis. Prentice Hall Inc., NewJersey. 1998. 